\title{
GHARAR DALAM AKUNTANSI AKRUAL
}

\author{
Ulfi Kartika Oktaviana \\ Fakultas Ekonomi UIN Maliki Malang \\ Jln. Gajayana No. 50 Malang, Hp. 081703406421 \\ e-mail: ulfiko@yahoo.com
}

\begin{abstract}
Abstrak
Some authors agreed that accrual basis concept is in line with the objectives of Islamic accounting. The ones who's agreed applying acrrual basis of accounting believes that the primary objective of Islamic Accounting information is to facilitate the users in computing his or her zakah obligation. The ones who's not agreed applying accrual basis believes that recognizing noncash and circumstances as they occur is contain gharar. They also believes in computing zakah obligation cannot apply accrual accounting because zakah must compute base on wealth which has been receive its benefit. Definition of accrual accounting also allow earning management to occur. Debate of the cash basis and the accrual basis has been long discussion, for financial statement of Islamic bank and financial institution need modified accrual and cash basis in order to fulfills Islamic Shari'a.
\end{abstract}

Key word: Gharar, Akuntansi Akrual, Akuntansi Kas, Laporan Keuangan Entitas Syariah.

Tujuan keseluruhan dari akuntansi adalah untuk menyediakan informasi yang dapat digunakan dalam pengambilan keputusan ekonomi. Sebagian besar sistem akuntansi dirancang untuk menghasilkan informasi untuk pelaporan eksternal dan internal. Pelaporan keuangan untuk pihak eksternal ini diatur oleh lembaga yang dibentuk untuk membuat standar atau prinsip-prinsip yang dirancang untuk mendefinisikan informasi apa yang yang harus diungkapkan kepada pihak luar. Standar akuntansi yang digunakan di Indonesia selama ini masih mengacu pada standar akuntansi Internasional. Dalam standar akuntansi salah satu asumsi dasar yang digunakan adalah asumsi dasar akrual, dengan itu laporan keuangan utamanya dibuat berdasarkan basis akrual.

Konsep akrual ini muncul karena akuntansi mendasarkan diri pada konsep upaya dan hasil dalam menentukan besarnya laba, akuntansi tidak membatasi pengertian biaya atau pendapatan pada biaya yang telah dibayar atau pendapatan 
yang telah diterima. Akuntansi lebih menekankan pada aspek substansi dari transaksi yang menimbulkan biaya dan pendapatan. Penandingan biaya dan pendapatan merupakan dasar digunakannya asas akrual dalam penyusunan laporan keuangan. Dalam konsep penandingan ini akuntansi berusaha memberikan dasar penandingan (basis for association) antara pendapatan dan biaya (biaya yang telah dianggap menghasilkan pendapatan tersebut dan dapat dibebankan terhadapnya) sehingga diperoleh laba yang tepat.

Akuntansi akrual bertujuan untuk memberikan informasi kepada pemakai mengenai konsekuensi aktivitas usaha terhadap arus kas perusahaan di masa depan secepat mungkin dengan tingkat kepastian yang layak. Hal ini dapat dicapai dengan mengakui pendapatan dan beban saat terjadi, tanpa memperhatikan apakah terdapat arus kas pada saat yang bersamaan. Pemisahan pengakuan pendapatan dan beban dengan arus kas difasilitasi dengan penyesuaian akrual, yang menyesuaikan arus kas masuk dan keluar untuk memperoleh pendapatan dan beban. Penyesuaian akrual dicatat setelah membuat asumsi dan estimasi yang layak, tanpa mengorbankan keandalan informasi akuntansi secara material. Karenanya, penilaian merupakan bagian terpenting dari akuntansi akrual, serta mekanisme aturan dan institusi yang diciptakan untuk memastikan keandalannya. Tujuan utama akuntansi akrual adalah membantu investor menilai kinerja keuangan entitas selama satu periode pelaporan.

Akrual didefinisikan oleh FASB (Financial Accounting Standard Board) sebagai "the accounting process of recognizing noncash and circumstances as they occur; specifically, acrual entails recognizing revenues and related increases in assets and expenses and related increases in liabilities for amounts expected to be receive or paid, usually in cash, in the future... (seperti dikutip oleh Belkaoui, 1992,p.195)

Kelolaan akuntansi akrual ini memberikan kesempatan manajer untuk melakukan manajemen laba. Sebagaimana diketahui bahwa earnings merupakan variabel penting dalam menilai kinerja suatu perusahaan bagi analis dan investor, kualitas earnings banyak dipengaruhi oleh manajeman laba yang dilakukan manajer. Dan salah satu cara menaikkan laba bisa dengan menaikkan nilai akrual kelolaan. Keleluasaan (dicretion) manajer dalam membuat judgments dan asumsi dalam akuntansi akrual sehingga mengakibatkan munculnya earnings management. Proses 
akrual banyak mendapat kritikan karena didasarkan pada kos historis dan karena laba yang dilaporkan dapat dimanipulasi melalui berbagai pilihan GAAP oleh manajer (Rayburn, 1986)

Di samping akuntansi berbasis akrual, terdapat sistem akuntansi lain yang didasarkan pada penerimaan dan pembayaran kas. Pendapatan dengan dengan basis akrual memberikan informasi lebih baik tentang kinerja keuangan dibandingkan dengan basis akuntansi kas. Perbedaan utama akuntansi akrual dan kas terletak pada perbedaan waktu pengakuan konsekuensi arus kas atas suatu aktivitas dan kejadian usaha.

Dasar akrual dalam (KDPPLK) Kerangka Dasar Penyusunan dan Penyajian Laporan Keuangan merupakan salah satu asumsi dasar laporan keuangan, dasar asumsi ini juga digunakan dalam penyusunan laporan keuangan entitas syariah seperti tercantum dalam KDPPLKS. Penggunaan dasar akrual inilah yang menjadi perdebatan para pemerhati akuntansi Islam. Penulis menemukan adanya perbedaan pendapat dalam penetapan dasar akrual pada penyusunan laporan keuangan entitas syariah dengan itu pendiskripsian masalah ini perlu dilakukan sebagai langkah kontribusi dalam upaya pencerahan masalah.

\section{Akuntansi Akrual Dalam Penyusunan Laporan Keuangan Entitas Syariah.}

Bangkitnya akuntansi syariah di Indonesia tidak hanya karena terpicu terjadinya skandal akuntansi sebuah perusahaan telekomunikasi yang berbasis di Amerika Serikat, WorldCom beberapa tahun silam. Tetapi akuntan syariah muncul sejalan dengan adanya kesadaran untuk bekerja lebih jujur, adil dan tidak bertentangan dengan ajaran Al-Qur'an dan Al-Hadist. Bangkitnya sistem akuntansi syariah itu dilatar-belakangi banyaknya transaksi dengan dasar syariah, baik yang dilakukan lembaga bisnis syariah maupun non syariah. Dengan animo itu, perlu adanya pengaturan atau standar untuk pencatatan, pengukuran, maupun penyajian sehingga para praktisi dan pengguna keuangan mempunyai standar yang sama dalam akuntansinya.

Ikatan Akuntan Indonesia (2007) menyatakan bahwa tujuan laporan keuangan bank syariah pada dasarnya sama dengan tujuan laporan keuangan secara umum yaitu menyediakan informasi yang menyangkut posisi keuangan, kinerja dan perubahan 
posisi keuangan suatu perusahaan yang bermanfaat bagi sejumlah besar pemakai dalam pengambilan keputusan ekonomi. Namun laporan keuangan bank syariah memiliki beberapa tambahan antara lain menyediakan:

a. Informasi kepatuhan bank terhadap prinsip syariah, serta informasi pendapatan dan beban yang tidak sesuai dengan prinsip syariah bila ada dan bagaimana pendapatan tersebut diperoleh serta penggunaannya

b. Informasi untuk membantu mengevaluasi pemenuhan tanggung jawab bank terhadap amanah dalam mengamankan dana, menginvestasikannya pada tingkat keuntungan yang layak, dan informasi mengenai tingkat keuntungan investasi yang diperoleh pemilik dan pemilik dana investasi terikat; dan

c. Informasi mengenai pemenuhan fungsi sosial bank, termasuk pengelolaan dan penyaluran zakat.

Ikatan Akuntan Indonesia (2007) menjelaskan bahwa asumsi dasar konsep akuntansi bank syariah sama dengan asumsi dasar konsep akuntansi keuangan secara umum yaitu konsep kelangsungan usaha (going concern) atas dasar akrual. Pendapatan untuk tujuan penghitungan bagi hasil menggunakan dasar kas.

Pengakuan pendapatan dalam akuntansi bank konvensional menggunakan dasar akrual. Artinya, pengaruh transaksi dan peristiwa lain diakui pada saat kejadian (bukan pada saat kas atau setara kas diterima atau dibayar) dan dicatat dalam catatan akuntansi serta dilaporkan dalam laporan keuangan pada periode yang bersangkutan. Dalam akuntansi syariah digunakan dua dasar yaitu dasar akrual (accrual basis) yang diterapkan untuk beban yang ditangguhkan, dan dasar kas (cash basis) yang digunakan untuk menentukan pendapatan. Pengakuan pendapatan untuk tujuan perhitungan bagi hasil, dilakukan pada saat diterima didasarkan pada ketentuan syariah yaitu pendapatan tidak dapat diakui sebelum diterima atau ditetapkan sebagai hak miliknya.

Apakah dasar akrual sesuai atau tidak dalam hukum atau syariah Islam, bisa kita lihat apakah dasar akrual satu arah dengan tujuan akuntansi Islam. Tujuan akuntansi Islam yang paling utama bagi beberapa pemerhati akuntansi Islam adalah untuk perhitungan zakat, jadi semua informasi laporan keuangan disusun untuk memfasilitasi perhitungan zakat. (Gambling dan Karim, 1991, Baydoun dan Willett, 
1994, Adnan, 1997, Triyuwono, 2006). Untuk tujuan tersebut, telah disepakati bahwa perhitungan zakat merupakan tujuan utama dalam penyusunan laporan keuangan. Dalam rangka untuk memenuhi tujuan tersebut Adnan percaya bahwa dasar akrual lebih baik dibandingkan dasar kas (Adnan, 1997).

Menurut Adnan, dasar akrual memberikan hasil laporan keuangan yang lebih mendekati realitas dari kinerja suatu entitas dibandingkan dasar kas dimana laporan keuangannya tidak menunjukkan hasil kinerja entitas yang sesunngguhnya atau kecenderungannya menunjukkan hasil yang lebih rendah dari sebenarnya. Dengan itu dasar kas tidak semestinya diterapkan dalam penyusunan laporan keuangan entitas syariah.

Para praktisi akuntan yang terwakili dalam IAI bersepakat bahwa dasar akrual tidak menyimpang dari hukum Islam dengan itu bisa digunakan sebagai dasar dalam penyusunan laporan keuangan syariah. Sebagaimana yang dinyatakan oleh Ellya Noorlisyati praktisi akuntan yang juga wakil ketua IAI Cabang Jakarta, ia mengingatkan bahwa suatu janji itu berdasarkan syariah juga wajib dipenuhi (Anonimous, 2007). Dasar pendapat ini bila diilustrasikan, seseorang yang menyewakan rumahnya. Jika si A mengontrakkan sebuah rumah, Rp 500 ribu per bulan, maka dia akan membukukan pendapatan selama satu tahun dari sewa rumah sebesar Rp 6 juta. Metode pembukuan seperti itu tidak akan bertentangan dengan kaidah Islam, karena sudah terjadi kesepakatan kontrak sewa, pemilik rumah dengan penyewa dengan harga Rp 500.000 per bulannya.

Pernyataan Standar Akuntansi Keuangan Perbankan Syariah di Indonesia (PSAK 59) dan KDPPLKS, yang merupakan hasil kerjasama antara Ikatan Akuntan Indonesia (IAI) dengan Bank Indonesia (BI) yang berisi aturan tentang Akuntansi Perbankan Syariah dan entitas syariah lain menyebutkan bahwa untuk mencapai tujuannya, laporan keuangan disusun atas dasar akrual. Dengan dasar ini, pengaruh transaksi dan peristiwa lain diakui pada saat kejadian (dan bukan pada saat kas atau secara kas diterima atau dibayar) dan diungkapkan dalam catatan akuntansi serta dilaporkan dalam laporan keuangan pada periode bersangkutan. 
PSAK Syariah yang disusun oleh Dewan standar akuntansi Indonesia sebagian besar masih merujuk pada standar akuntansi yang dibuat oleh AAOIFI (Accounting and Auditing Organization for Islamic Financial Institution) sebuah organisasi yang mengembangkan akuntansi dan auditing bagi lembaga keuangan syariah di tingkat dunia. AAOIFI menerapkan dasar akrual dalam penyusunan laporan keuangan lembaga keuangan syariah. Konsep akrual ini diterima AAOIFI dengan mengacu pada pendapat dari Umar bin Khattab (Napier,2007) : "Nilailah barang daganganmu dan bayarlah zakatnya (jika telah masuk nisab dan haulnya)". Hal ini memberi implikasi bahwa zakat harus dibayar atas kekayaan yang meningkat dan konsep ini paling baik untuk menilai kekayaan(Nurhayati dan Wasilah, 2008).

Adapun alasan penggunaan dasar akrual yakni laporan keuangan dapat diperbandingkan dengan laporan keuangan lembaga lainnya, karena secara umum semua prinsip yang dianut dalam laporan keuangan adalah konsep dasar akrual (Batu bara, 2009). Dalam melakukan pengakuan pendapatan secara akrual untuk lembaga keuangan khususnya perbankan ditetapkan ketentuan sebagai berikut : Pengakuan pendapatan atas aktiva produktif yang performing, yaitu aktiva produktif yang mempunyai kualitas lancar dan dalam perhatian khusus. Apabila terjadi perubahan pengakuan pendapatan atas aktiva produktif yang non performing, yaitu aktiva produktif dengan kualitas kurang lancer, diragukan, dan macet diterapkan jurnal balik, dan dicatat dalam rekening administrative. Pengakuan pendapatan akrual untuk penyaluran dengan prinsip bagi hasil (pembiayaan mudharabah dan pembiayaan musyarakah), hanya diperkenankan apabila telah diperoleh laporan pengelolaan dana mudharabah yang dapat dipertanggung jawabkan dengan mudharib (debitur).

\section{Unsur Gharar Dalam Akuntansi Akrual}

Bebas dari Riba dan gharar adalah dua norma yang paling penting dalam transaksi syariah. Pelarangan riba secara luas telah dibahas banyak peneliti-peneliti, namun pembahasan gharar belum seluas pembahasan riba. Gharar dalam bahasa Arab adalah al-khathr (pertaruhan). Gharar dalam istilah dinyatakan sebagai sesuatu yang mengandung ketidakjelasan, keraguan, tipuan atau tindakan yang merugikan orang lain. Gharar pada istilah para fuqaha, antara lain Al- Sarkhasi dari mazhab Hanafi berpendapat gharar ialah barang yang tersembunyi dan tidak diketahui akibatnya. Al- 
Qarafi dari mahzhab Maliki berpendapat asal gharar ialah barang yang tidak diketahui apakah bisa didapatkan atau tidak, seperti burung di udara atau ikan di laut (dikutip dari Zaroni, 2007). Sedangkan menurut Syaikh As-Sa'di, al-gharar adalah almukhatharah (pertaruhan) dan al-jahalah (ketidakjelasan) (Abdurrahman, 1992).

Gharar dikategorikan dan dibatasi terhadap sesuatu yang tidak dapat diketahui antara tercapai dan tidaknya suatu tujuan, dan tidak termasuk di dalamnya hal yang majhul (tidak diketahui) (Abdul, 1416H). Seperti definisi yang dipaparkan oleh Ibn Abidin yaitu, "gharar adalah keraguan atas wujud fisik dari obyek transaksi". Gharar dibatasi dengan sesuatu yang majhul (tidak diketahui), dan tidak termasuk di dalamnya unsur keraguan dalam pencapaiannya. Definisi ini adalah pendapat murni mazhab Dhahiri. Ibn Haz mengatakan "unsur gharar dalam transaksi bisnis jual beli adalah sesuatu yang tidak diketahui oleh pembeli apa yang ia beli dan penjual apa yang ia jual". Kombinasi antar kedua pendapat tersebut di atas, yaitu gharar meliputi dalam hal yang tidak diketahui pencapaiannya dan juga atas sesuatu yang majhul (tidak diketahui). Contoh dari definisi ini adalah yang dipaparkan oleh Imam Sarkhasi: "gharar adalah sesuatu yang akibatnya tidak dapat diprediksi. Ini adalah pendapat mayoritas ulama fiqh (Ghufran,2002). Gharar dalam standar akuntansi keuangan dijelaskan sebagai transaksi yang berpotensi merugikan salah satu pihak karena mengandung unsur ketidakjelasan, manipulasi dan eksploitasi informasi serta tidak adanya kepastian pelaksanaan akad (SAK,2007).

Beberapa pemerhati akuntansi Islam salah satunya mantan Dirut Bank Muamalat, Zainulbahar Noor berpendapat bahwa dalam dasar akrual mengandung unsur gharar dimana dinyatakan bahwa sistem accrual basis, telah mengakui adanya pendapatan yang terjadi di masa yang akan datang (Anonimous, 2007). Aji dedi berpendapat asumsi tersebut sangat bertentangan dengan prinsip dan akhlak syariah bahkan tujuan laporan keuangan akuntansi syariah (Dedi, 2008). Mereka yang tidak menerima konsep akrual juga menyatakan bahwa konsep ini tidak dapat dipakai sebagai cara menghitung zakat mengingat zakat harus dibayar berdasarkan kekayaan yang telah diterima manfaatnya (menurut Mazhab Maliki) dan juga bagi hasil atas mudharabah didasarkan atas keuntungan kas yang diterima (menurut Mazhab Syafi'i) dikutip dari Nurhayati dan Wasilah, 2008. Dasar ini telah menjawab penggunaan pendapat Khalifah Umar bin Khattab mengenai penilaian kekayaan untuk perhitungan zakat sebagai pengesahan penerapan akuntansi akrual. 
Dalam asumsi dasar akrual tidak sepenuhnya dapat digunakan secara langsung. Seperti diketahui bahwa prinsip akrual melakukan pencatatan fakta (merekam arus kas masa kini), potensi (merekam arus kas masa depan) dan konsekuensi (merekam arus kas masa lalu). Khusus mengenai pencatatan potensi menggunakan prinsip present value yang sarat dengan penghitungan bernuansa riba dan gharar. Sedangkan syariah Islam melarang untuk mengakui suatu pendapatan yang sifatnya belum pasti.( Hal ini disebabkan karena masa yang akan datang adalah kekuasaan dan wewenang Allah sepenuhnya untuk mengetahuinya (Baca QS AlBaqarah:255).

Menurut Zainul, penerapan metode akrual basis dalam pengakuan pendapatan akan menyebabkan bank, asuransi atau usaha yang berbasiskan pada syari'ah melanggar syariat Islam. Bahkan, dapat disimpulkan penerapan metode accrual basis merupakan loop hole bagi terjadinya korupsi (Anonimous, 2007). Bagi pengkritik metode akrual menganggap sistem tersebut tidak cocok dalam syariah, karena memberikan banyak pintu untuk memungkinkan terjadi penyimpangan loop hole yang mengarah terjadinya korupsi. Pada tahap awal biasanya dimulai dalam bentuk pempublikasian neraca dan laba rugi akhir tahun yang bersifat window dressing. Manajer pada akhir tahun cenderung menggelembungkan angka pendapatan dengan maksud untuk menaikkan tingkat laba melalui perlipatgandaan angka pendapatan, laba, dengan mengkredit pos pendapatan dari pendebetan pendapatan yang akan diterima (Interest Earned Not Collected/IENC). Cara ini dilakukan dalam upaya meyakinkan masyarakat bahwa perusahaan bersangkutan menguntungkan untuk menarik dana masyarakat lebih banyak dan maksud lainnya, antara lain mengarah pada tindakan kriminal dalam keuangan perusahaan. Pemikiran Zainul memang didasari dari beberapa penelitian yang menunjukkan metode akrual memberikan peluang bagi manajer untuk melakukan earning management. Metode akrual ini membolehkan para manajer untuk membuat judgment dan asumsi dalam menyusun dan melaporkan kinerja keuangan perusahaan mereka. Judgment dan asumsi yang dibuat tersebut tidak hanya dapat meningkatkan keinformatifan laba akuntansi tetapi juga memunculkan kemungkinan bagi manajemen untuk berperilaku oportunistis dengan perilaku ini manajer akan cenderung melakukan earning management (Rahman, 2005). Penelitian Kiswara (1999) menggali kebijakan akuntansi akrual di Indonesia, mengarah pada indikasi keberadaan earning management dalam 
pengungkapan laporan keuangan tahunan perusahaan publik. Tindakan earning management inilah yang dinyatakan sebagai loop hole munculnya penyimpangan.

Akuntansi akrual mengenalkan penilaian dalam akuntansi dengan berbagai estimasi dan penyesuaian. Idealnya adanya penilaian manjerial dapat meningkatkan relevansi informasi akuntansi. Namun kenyataannya tidak sesuai dengan kondisi ideal. Penggunaan penilaian bisa mengurangi "kualitas dapat dibandingkan" dan "konsistensi" atas laporan keuangan yang dapat mengarah pada distorsi akuntansi (Wild, Submaramanyam, Halsey, 2005)

Bagi pengkritik metode akrual, sistem ini (acrual basis) tidak sensitif dalam mencegah terjadinya kejahatan keuangan. Kasus WorldCom, Enron, semula berawal dari sini. Laporan keuangan mereka bagus, tapi cash flow mereka buruk. Itu terjadi, karena pendekatan dasar akrual memang membuka peluang trik-trik curang dalam pembukuan. Tragedi WorldCom terjadi karena akuntannya memanfaatkan lubanglubang dasar akrual, yang pada akhirnya merugikan para pemilik saham. Kebangkrutan itu dikarenakan banyak keuntungan yang masih berbentuk potensi dibukukan dan diakui sebagai pendapatan.

\section{Akuntansi Akrual dan Akuntansi Kas}

Akuntansi akrual sudah lama menjadi perdebatan mengenai keandalannya memberikan informasi keuangan. Sebagai tandingan dari dasar akrual adalah dasar kas, perbedaan utama dari keduanya terletak pada perbedaan waktu pengakuan konsekuensi arus kas atas suatu aktivitas dan kejadian usaha. Akuntansi akrual mengatasi masalah tepat waktu maupun pengaitan yang selalu terdapat dalam akuntansi kas. Masalah tepat waktu ini mengacu pada arus kas yang tidak selalu bersamaan dengan aktivitas usaha yang mengahsilkan kas tersebut. Masalah penandingan atau pengaitan (matching) mengacu pada arus kas masuk dan arus kas keluar yang disebabkan oleh aktivitas usaha yang tidak dapat dikaitkan dengan waktu terjadinya.

Akuntansi kas memiliki nilai keandalan dibandingkan akuntansi akrual. Penerapan dasar kas alokasi, taksiran. penyusutan, dan berbagai taksiran penyisihan. Keandalan akuntansi kas nampak pada kemampuannya memberikan penilaian tentang likuiditas perusahaan. Sebagaimana diketahui akuntansi akrual memang tidak 
sempurna dan banyak aturan yang berubah-ubah, kesalahan estimasi dan adanya earning management yang mendistorsi akrual. Namun keunggulan konseptual akuntansi akrual dibandingkan arus kas adalah karena laporan laba rugi dan neraca berbasis akrual lebih relevan untuk mengukur kapasitas perusahaan untuk menghasilkan kas saat ini dan pada masa mendatang.

Keunikan produk dan jasa pada entitas syariahlah yang mendorong penerapan standar ini akuntansi yang berbeda dengan standar akuntansi yang konvensional. Salah satu keunikannya adalah penerapan 'modified cash basis'. Sebelumnya dinyatakan bahwa pendapatan atau income harus diakui dengan menggunakan cash basis, tetapi untuk kasus-kasus tertentu, prinsip ini perlu ditinjau lagi, atau bahkan dimodifikasi. Kasus tertentu tersebut bisa kita temui dalam kontrak mudharabah dimana bank bertindak sebagai sahibul maal dan juga sebagai mudharib pada kontrak yang lain. Apabila pendekatan cash basis diterapkan dalam penentuan bagi hasil deposito mudharabah, dimana bank memberikan bagi hasil dengan jangka waktu yang bergantung pada keunikan usaha dari mudharib. Bagaimana dengan pemberian bagi hasil bagi pihak nasabah yang bertindak sebagai shaibul maal yang mana jangka waktunya tidak sama dengan pemberian bagi hasil bagi nasabah yang bertindak sebagai mudharib. Penerapan modified cash basis pada kasus ini sebagai hasil dari ijtihad untuk memberikan keadilan bagi semua nasabah baik yang bertindak sebagai mudharib maupun shahibul maal bisa mendapatkan bagi hasil yang adil.

Pada dasarnya bank syariah menganut konsep akrual khususnya untuk beban yang diungkapkan dalam laporan laba rugi, sedangkan untuk pendapatan harus dilakukan secara hati-hati tergantung dari opini dewan syariah setempat apakah menggunakan dasar kas atau akrual. Pengadopsian sistem akrual basis dalam pelaporan keuangan bank konvensional dengan bank syariah berbeda. Bank konvensional boleh mengakrualkan pendapatan selama itu masuk katagori collectibility atau kalaupun pernah menunggak tidak lebih dari tiga bulan. Di luar itu, tidak boleh diakrualkan. Dengan menggunakan sistem bunga, maka tidak ada korelasi antara apa yang didapatkan dengan apa yang dibayarkan kepada nasabah.

Berbeda dengan bank syariah yang berpolakan bagi hasil. Sebab, bank itu harus menghasilkan pendapatannya. "Jadi ada korelasi erat antara pendapatan dan bagi 
hasil". Karena itu, akan sulit melakukan koreksi bila metode akrual basis diterapkan. Seperti misalnya, mencatatkan pendapatan yang belum pasti sebagai bagian pendapatan itu sendiri, dan dikemudian hari pendapatan itu tidak diterima, jadi bagaimana bisa direcord sebagai penghasilan. Dari uraian di atas dapat disimpulkan bahwa untuk kepentingan laporan keuangan menggunakan dasar akrual sedangkan untuk kepentingan perhitungan bagi hasil mempergunakan dasar kas, yang dalam pelaksanaannya bukan merupakan hal mudah, karena bank syariah dituntut untuk mempunyai administrasi yang baik dan akurat sehingga dapat membedakan pendapatan akrual dan pendapatan yang diterima secara kas.

\section{KESIMPULAN}

Penolakan penerapan dasar akrual dalam penyusunan laporan keuangan entitas syariah telah dikemukakan oleh beberapa pemerhati akuntansi Islam dengan alasan bahwa dasar akrual tidak sesuai dengan syariah karena adanya unsur gharar. Dimana unsur gharar dalam akuntansi akrual menyangkut adanya unsur ketidakpastian dalam pengakuan pendapatan. Sebagaimana diketahui akuntansi akrual ini mengakui pendapatan dan beban pada saat terjadinya aktivitas usaha bukan pada saat realisasi kasnya. Kelemahan dasar akrual dalam keandalan penyajian laporan keuangan disebabkan salah satunya adalah keleluasaan akrual yang memberikan oportunitis manajer untuk melakukan earning management.

Menurut pengkritik dasar akrual, penggunaan dasar kas lebih diutamakan diamana dasar ini mengacu pada prinsip kehati-hatian yang berlandaskan ajaran Islam yang mengatakan bahwa “...Dan tiada seorang pun yang dapat mengetahui dengan pasti apa yang akan diusahakannya esok hari..." (an-Nuur: 34) sehingga tidak seharusnya mengakui pendapatan sebelum nyata-nyata berbentuk aliran kas yang secara riil masuk ke entitas syariah.

Meskipun informasi akuntansi akrual tidak sempurna, namun hasil beberapa uji empiris menunjukkan bahwa akuntansi akrual memberikan penilaian kinerja dan kondisi keuangan entitas syariah yang relevan. Salah satu penelitian analisis 
menemukan bahwa akrual jangka pendek lebih berguna dalam penilaian perusahaan (Dechow, 1994). Dalam jangka panjang tidak ada perbedaan hasil antara dasar akrual dengan dasar kas, namun dalam jangka pendek keterbatasan dasar kas akan nampak dengan jelas. Pengukuran kinerja keuangan akan lebih berarti bila didasarkan pada masa interval yang pendek dibandingkan interval yang panjang.

Isu akuntansi berbasis kas atau berbasis akrual memang sudah lama dan sebenarnya tidak begitu relevan dipertentangkan. Keduanya adalah saling mengisi atau komplementer. Basis kas akan melahirkan informasi tentang likuiditas yang sangat perlu bagi para pengambil keputusan. Akuntansi berbasis akrual sangat perlu untuk menyusun laporan laba rugi dan laporan posisi keuangan (Neraca). Bahkan laporan kontinjensi pada industri perbankan yang berbasis risiko masa depan juga perlu disajikan apalagi dalam situasi ekonomi yang semakin tidak pasti seperti yang jelas dipraktekkan khususnya dalam industri perbankan.

Penerapan dasar akrual dalam lembaga keuangan syariah atau entitas syariah tidak bisa dilakukan secara total keseluruhan karena sifat dasar usaha yang berbeda dengan yang konvensional. Keunikan dasar transaksi dalam entitas syariah tidak membolehkan angka pendapatan hasil pengukuran dengan akuntansi akrual digunakan untuk dasar perhitungan bagi hasil. Pembagian hasil usaha dalam entitas syariah mesti didasarkan dari kas yang diterima dan hal ini telah diadopsi oleh Standar Akuntansi Keuangan Syariah. Penggunaan akuntansi kas secara keseluruhan dalam prakteknya belum digunakan untuk pelaporan keuangan ke publik. Trade off antara keandalan dan relevansi merupakan salah satu dasar pemikiran penentuan penggunaan akuntansi kas maupun akuntansi akrual. Pertimbangan penggunaan akuntansi akrual maupun akuntansi kas mesti dikaji dengan sebaik-baiknya dengan tujuan untuk kepentingan kemaslahatan ummat. 


\section{DAFTAR PUSTAKA}

Al-Qur'anul Karim dan terjemahannya. Tafsir.

AAOIFI. 2003. Accounting, Auditing ang Governance Standards for Islamic Financial Institution. Bahrain.

Adnan, A. 2005. Akuntansi Syariah: Arah, Prospek dan Tantanganya. UII Press. Yogyakarta.

Abdurrahman bin Nashir As-Sa'di. Th 1992M .Bahjah Qulub Al-Abrar wa Qurratu Uyuuni Al-Akhyaar Fi Syarhi Jawaami Al-Akhbaar. Tahqiq Asyraf Abdulmaqshud, Cet. II, , Dar Al-Jail. Hal.164

Abdul Azhim Badawi. Th.1416H .Al-Waaji Fi Fiqhu Sunnah wa kitab Al-Aziz. Cet. I. Dar Ibnu Rajab, Hal. 332

2007. Akuntansi Syariah vs Barat. Majalah Akuntan Indonesia. Edisi 2. IAI. Jakarta

Batu Bara, Z. 2009. Asumsi Dasar Akuntansi Perbankan Syariah. Blog Akuntansi Syariah Zakariah Batu Bara

Baydoun, N and R. Willett.1994. Islamic Accounting Theory. Paper dipresentasikan pada AAANZ Annual Conference. 3-6 July 1994. Wollongong. Australia.

Belkaoui, A.R. 1992. Accounting theory. Third Edition. Academic Press. Harcourt Brace Jovanivich. Publisher. London.

Dechow, P.M. 1994. "Accounting Earnings and Cash Flows as Measures of Firm Performance : The Role of Accounting Accruals". Journal of Accounting and Economics 18. Hal 3-42.

Gambling, T and Karim, R.A.A.1991. Business and Accounting Ethics in Islam, Mansell. London.

Kiswara, E.1999. “Indikasi Keberadaan Unsur Manajemen Laba (eraning management) dalam Laporan Keuangan Perusahaan Publik" Tesis S2 tidak dipublikasikan UGM.

Mas'adi, Ghufran A.,2002. Fiqh Muamalah Kontekstual,: PT. Raja Grafindo Persada.

Jakarta. 
Napier dan Christopher. 2007-2008. Defining Islamic Accounting : Current Issues Past Roots. Napier's Paper in the 5th Accounting History International Conference. Kanada.

Nurhayati, S dan Wasilah. 2008. Akuntansi Syariah di Indonesia. Salemba Empat. Jakarta.

Pernyataan Standar Akuntansi Keuangan. 2007. Ikatan Akuntan Indonesia

Rahman, Aulia Fuad. 2005. Akuntansi Akrual : Suatu Kesempatan Berperilaku Oportunistis. Lintasan Ekonomi. Lembaga Penerbitan dan Publikasi Ilmiah FE UB.

Rayburn, J. 1986. “The Association of Operating Cash Flow and Accruals with Security Returns". Journal of Accounting Research 24. Supplemen hal 112-133.

Triyuwono, Iwan. 2006. Perspektif, Metodologi dan Teori Akuntansi Syariah. Raja Grafindo Persada. Jakarta.

Wild,Subramanyam dan Halsey. 2005. Analisis laporan Keuangan. Salemba Empat. Jakarta.

Zaroni, Akhmad Nur. 2007.Jual Beli Gharar - Tinjauan terhadap Proses dan Obyek Transaksi Jual Beli. Mazahib. Vol IV.Samarinda. 